\title{
II
}
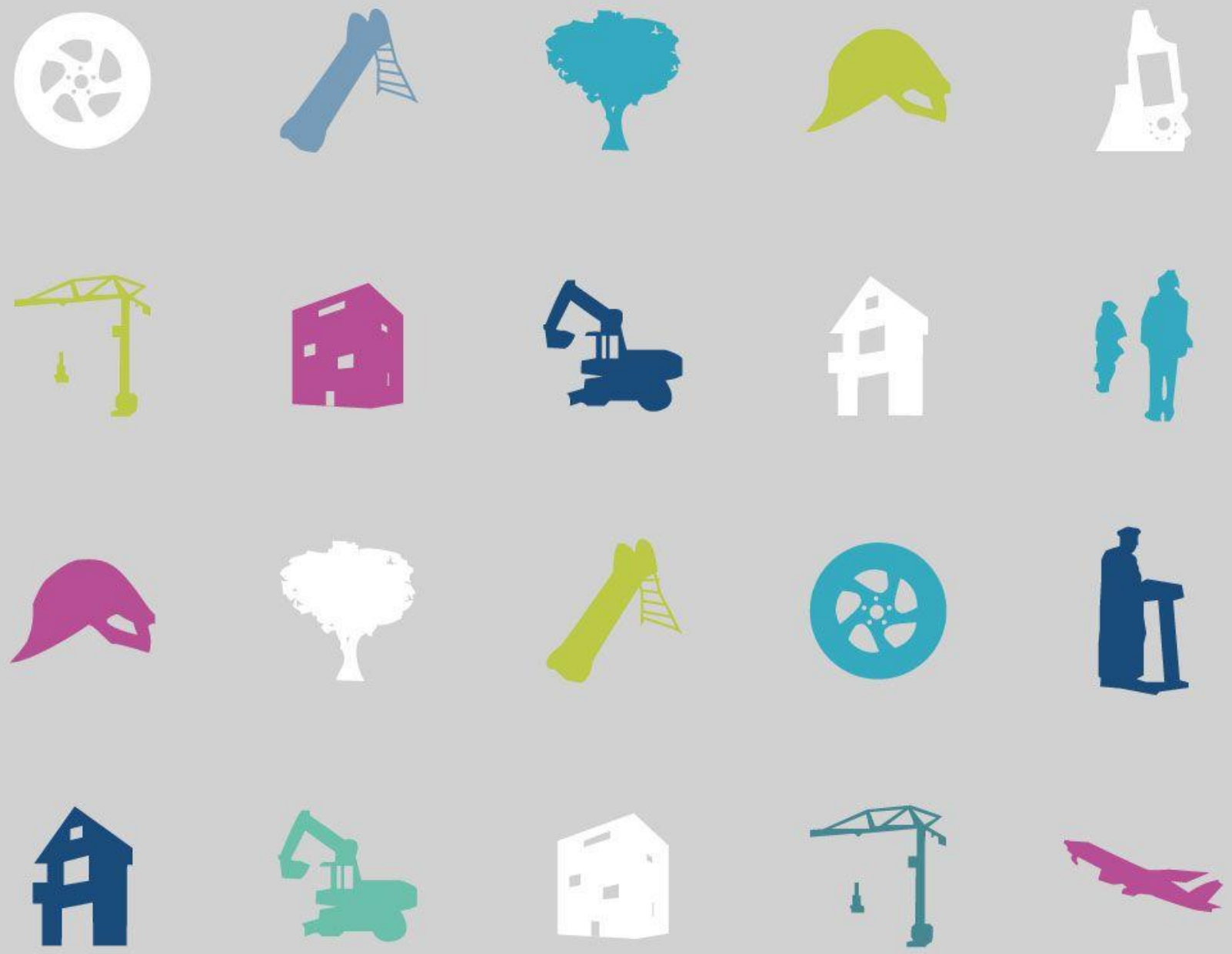

\section{Maturation of the Dutch social housing model and perspectives for the future}

Peter Boelhouwer
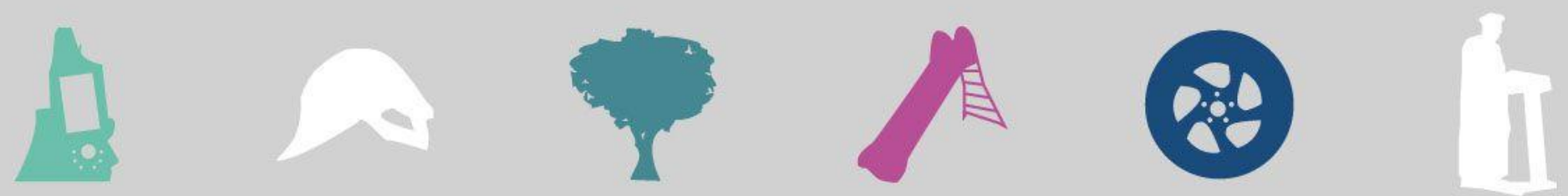
OTB - Research for the Built Environment

Delft University of Technology

Jaffalaan 9, 2628 BX Delft, The Netherlands

Tel. $+31(0) 152783005$

Fax $+31(0) 152784422$

E-mail mailbox@otb.tudelft.nl

http://www.otb.tudelft.nl

(c) Copyright 2014 by OTB Research Institute for the Built Environment

No part of this report may be reproduced in any form by print, photo print, microfilm or any other means, without written permission from the copyright holder.

OTB - Research for the Built Environment seeks to make a visible contribution to society by helping to solve social problems in the field of the built environment. We do this by means of our specialist scientific research in this area as part of Delft University of Technology and in close cooperation with faculties. The emphasis lies on scientific impact and social relevance. We aim to increase the significance of scientific research, while continuing to focus on the vital exchange between problem-oriented and practically applicable research. 


\title{
Maturation of the Dutch social housing model and perspectives for the future
}

\author{
Peter Boelhouwer
}

Delft University of Technology, OTB Research Institute for the Built Environment, P.O. Box 5030, 2600 GA Delft, the Netherlands, e-mail: p.j.boelhouwer@tudelft.nl

OTB Working papers 2014-05

\begin{abstract}
The Dutch social rented sector has acquired an international reputation because of its social nature and the way it has evolved. With around $32 \%$ of the total stock, the size of the sector is much bigger than in other western European countries. Also the development after the second world war is unique. This current position is determined by the specific structure of the Dutch welfare state and the country's distinct housing policy. It is also the result of the shifting balance of supply and demand in the national housing policy. In this paper we explain the development of the Dutch social rented sector on the basis of the above mentioned characteristics.

We start with an international comparison in which the position of the Dutch sector is positioned. We will also pay attention to the background of the successful development of this sector: the financing system, the unique guarantee system and the interplay between the central government and the local housing associations.

The contribution concludes with an exploration of the future of the social rented sector in the Netherlands. The sketch is specifically concerned with the development options for the social rented sector in the next few years. Due to all kind of processes and developments, the social rented sector in the Netherlands is nowadays on a crossroad and important policy decisions have to be made.
\end{abstract}

Keywords: housing policy, housing associations, welfare systems, the Netherlands, housing systems 


\section{Introduction}

The housing system of the Netherlands has acquired an international reputation because of its special nature and the way it has evolved. Over the past years, the Dutch housing system has been a source of inspiration for policy-makers far and wide, including scholars and officials from some of the former socialist states in Eastern Europe and several Asian nations. Researchers and policy-makers in those countries have shown keen interest in the way social rented housing is operated in the Netherlands. In particular, they are intrigued by the strong position of social housing in this country: 41 per cent of the total housing stock of the Netherlands was accounted for by this sector at the beginning of the 1990s. The Netherlands clearly stands out in this sense; the share of this sector in most other West European countries rarely reaches 20 per cent. The strong position of Dutch social housing has its roots in the long period during which housing was influenced by national government. Of course, public intervention had been common practice throughout the Western Europe for decades. However, the Netherlands eventually came to steer its own course. Whereas most other West European countries veered toward privatisation in the early 1970s, the Netherlands did not start to move in that direction until the 1990s.

The objective of this contribution is to explain how the Dutch social rented sector came to have the specific character for which it is renowned. To place this social institution within its societal context, section 2 gives an theoretical perspective. More specific, the characteristics of the different welfare states in Western Europe are presented. The presented welfare state typology makes it possible to structure the position of the social rented sector in Europe and the Netherlands in a theoretical perspective. Section 3 elaborates on the direction in which Dutch housing policy developed and the role that the social rented sector played in that overall policy. It will be shown that there are clear links with the transformation of the welfare state, as described in the preceding section. This also clarifies the special position of housing as a policy field between the state and the market, or, as Harloe (1995) and Torgersen (1987) had characterised it earlier, "housing as the wobbly pillar under the welfare state." One of the success factors of the social rented sector in the Netherlands is the institutional structure and more specific the way the financing of the sector is organised. The inventive interplay between state guarantees and the revolving fund principle created a unique situation where housing associations can flourish and are able to initiate more than half of the building production in the Netherlands in 2012, without any direct financial state aid. Section 4 explains this unique collaboration between the housing associations and the state. Like many other West European countries, the welfare state and also the position of the intermediate sector in the Netherlands is under pressure. The different policy options are discussed in section 5. This sketch is specifically concerned with the development options for the social rented sector in the next few years. In that light, it emphasises the strategic decisions that will have to be made soon. Finally, this paper ends with some concluding remarks.

\section{Theoretical perspective}

The development of the social rented sector in Europe has been described by several authors in the past (Boelhouwer and van der Heijden, 1992; Danermark and Elander, 1994; Harloe, 1992, 1994, Murie, 1992). As noted by many of these authors before (see for an overview Danermark and Elander, 1992, p.2) the concept of social housing although used as if its meaning was self-evidently clear, takes on different meanings in various national contexts. Sometimes it is connected to council housing (like in the UK), sometimes as publicly subsidized housing, irrespective of ownership (like in Germany), sometimes as intermediate housing (like in the Netherlands) or as an umbrella concept, covering various types of housing in terms of ownership and tenure. Nevertheless, de- 
spite these and other differences, historically the term social housing has been ascribed some dimensions that are quite similar from country to country thus making comparative discussion meaningful (Danermark and Elander, 1992, p.2). As summarized by Harloe (1992), social rented housing can be very broadly characterized as having three major characteristics: First, it is provided by landlords at a price which is not primarily determined by considerations of profit. Second, it is administratively allocated according to some conception of 'need'. Third, government control over social rented housing is extensive and has become more some over time. With regard to this last characteristic, things have changed in the last decade. Social landlords in for instance the Netherlands are much more independent from the government than they were before.

In Boelhouwer and Hoekstra (2012, p.369-370), we constructed an adjusted welfare state typology. This typology is based on the typology of Esping-Andersen (1990) and Kemeny (1995). On the basis of the changing role of the central government in many Western European countries in the 1990s, we subdivide Kemeny's capital-led corporatism into two types: conservative corporatism, and modern corporatism. Conservative corporatism corresponds with corporatism as defined by Esping-Andersen. In this definition the state is fairly active in the provision of welfare services. However, this does not lead to income redistribution, since preservation of the existing hierarchy in society is the starting-point for welfare policies at State level. Consequently, the welfare provision is segmented; different groups are entitled to different welfare services; and the traditional family is often explicitly favoured. Furthermore, the state is definitely not the only provider of welfare services. In this respect, the family and private non-profit organisations also play an important role. Modern corporatism refers a style of governance in which central government switches to a more indirect style of governance in which the central government defines the policy frameworks within which the local authorities and the private actors operate. Thus, next to liberalism, we distinguish three different kinds of corporatism: labour-led, conservative, and modern.

Table 1 shows how the various welfare state regimes of the modified theoretical framework differ with respect to these characteristics.

Table 2 Main characteristics of the four welfare state regimes according to the modified theoretical framework

\begin{tabular}{|c|c|c|c|c|}
\hline & $\begin{array}{l}\text { Labour-led cor- } \\
\text { poratist }\end{array}$ & $\begin{array}{l}\text { Conservative- } \\
\text { corporatist }\end{array}$ & $\begin{array}{l}\text { Modern corporat- } \\
\text { ist }\end{array}$ & Liberal \\
\hline De-commodification & • $\quad$ high & - relatively high & - $\quad$ relatively high & - $\quad$ low \\
\hline $\begin{array}{l}\text { Influence of central } \\
\text { government }\end{array}$ & - $\quad$ high and direct & $\begin{array}{l}\text { - } \text { quite high and } \\
\text { often indirect }\end{array}$ & $\begin{array}{l}\text { - } \text { quite high and } \\
\text { often indirect }\end{array}$ & - low \\
\hline $\begin{array}{l}\text { Degree of political } \\
\text { corporatism }\end{array}$ & $\begin{array}{l}\text { - } \\
\text { many corporat- } \\
\text { ist structures } \\
\text { and processes }\end{array}$ & $\begin{array}{l}\text { many corporat- } \\
\text { ist structures } \\
\text { and processes }\end{array}$ & $\begin{array}{l}\text { many corporat- } \\
\text { ist structures } \\
\text { and processes }\end{array}$ & $\begin{array}{l}\text { - few corporatist } \\
\text { structures and } \\
\text { processes }\end{array}$ \\
\hline $\begin{array}{l}\text { Fragmentation in the } \\
\text { provision of welfare } \\
\text { services }\end{array}$ & $\begin{array}{l}\text { fragmentation } \\
\text { on the basis of } \\
\text { measurable cri- } \\
\text { teria }\end{array}$ & $\begin{array}{l}\text { fragmentation } \\
\text { on the basis of } \\
\text { occupation } \\
\text { and/or social } \\
\text { status }\end{array}$ & $\begin{array}{l}\text { fragmentation } \\
\text { on the basis of } \\
\text { measurable cri- } \\
\text { teria }\end{array}$ & $\begin{array}{l}\text { fragmentation } \\
\text { on the basis of } \\
\text { measurable cri- } \\
\text { teria. }\end{array}$ \\
\hline $\begin{array}{l}\text { Treatment of the tra- } \\
\text { ditional family in wel- } \\
\text { fare policies }\end{array}$ & $\begin{array}{l}\text { - } \begin{array}{l}\text { no preferential } \\
\text { treatment for } \\
\text { the traditional } \\
\text { family }\end{array} \\
\end{array}$ & $\begin{array}{l}\text { preferential } \\
\text { treatment for } \\
\text { the traditional } \\
\text { family }\end{array}$ & $\begin{array}{l}\text { - } \text { no preferential } \\
\text { treatment for } \\
\text { the traditional } \\
\text { family }\end{array}$ & $\begin{array}{l}\text { no preferential } \\
\text { treatment for } \\
\text { the traditional } \\
\text { family }\end{array}$ \\
\hline $\begin{array}{l}\text { Role of State, market, } \\
\text { and family in the pro- } \\
\text { vision of welfare ser- } \\
\text { vices }\end{array}$ & $\begin{array}{l}\text { dominant posi- } \\
\text { tion of the State }\end{array}$ & $\begin{array}{l}\text { important (if } \\
\text { not dominant) } \\
\text { position of the } \\
\text { family }\end{array}$ & $\begin{array}{l}\text { - welfare services } \\
\text { are provided by } \\
\text { both market } \\
\text { and State }\end{array}$ & $\begin{array}{l}\text { - dominant posi- } \\
\text { tion of the mar- } \\
\text { ket }\end{array}$ \\
\hline
\end{tabular}


With this above explained adjusted welfare state typology it's also possible to structure the position of the social rented sector more precisely. Kemeny's elaboration between home-owning and cost rental societies could be the starting point. In his article "Corporatism and Housing Regimes" (Kemeny, 2006), argues on the basis of a division between capital-led and labour led corporatism that there is a connection between the specific corporatistic welfare state and the existence of an integrated rental market with a strong social rented sector. Kemeny argues that the corporatist power system indices the need to achieve compromises. Corporatist compromise solutions entail a political solution that takes into consideration several different interests. The fragmentation of political parties resulting in coalitions and minority governments being the norm may be part of the explanation for the rise of an integrated market and a strong social rented sector. The latter can take many shapes and forms such as municipality-owned companies, voluntary or charitable societies, trusts, rental cooperatives and even privatelyowned non-profit enterprises (Kemeny, 2006, p.12). For right wing hegemonic coalitions who could be classified as liberal welfare states it's quite clear that there will be a choice for a dualist rental system, where non-profit activities are restricted and nationalised. Social rented housing is incorporated into a publicly-controlled planned economy and shaped into a low-income housing sector (command economy means-tested public renting). Examples are the USA, Canada, Australia new Zealand and to a lesser degree the UK. The corporatist welfare states are more related to an integrated rental market with a specific leading role for the social rented sector (Kemeny, 2006, p.13). In conservative corporatist countries we could aspect still a strong influence of right wing parties and a social rented sector which is limited and has a limited impact on the rental market. We also could expect a variety of ownership forms of social rental housing. Examples of these countries are Germany and Switzerland. In the labour-led corporatist countries we would expect a bigger and more uniform social rented and a very small profit rented sector. The social rented sector is than big enough to have a leading position on the rental market. Also the influence of the tenant and/or the state could be more explicit. Clear examples of these type of corporatist states are Sweden and Denmark. In the modern corporatistic welfare state, the role of the state is smaller and the role of the market, also for the social rented sector, is bigger than in the labour-led corporatistic state. A clear example of that is the social rented sector in the Netherlands. With $33 \%$ of the housing stock, the social rented sector in the Netherlands has still a dominated position not only in the Dutch rental market, but also in the overall housing market. The state largely confines itself to creating the conditions and to formulate the policy frameworks within which local government authorities and private actors operate. This new policy framework brought the housing associations in the Netherlands into a very powerful position. They are financially very strong and are in the bigger cities dominating the local rental market with regard to their housing stock and have a crucial role in urban renewal developments. A relevant question for the future is if more corporatist welfare states will develop into the direction of a modern corporatistic welfare state and if the right parties and the liberal oriented neo-classical economies will approve such a development. More specific the role of the European commission and the way the policy of free competition is implemented in the near future by specific laws from Brussels, will probably give an answer to the question if corporatistic welfare states in general will have a bright future.

\section{Developments in Dutch housing policy and the role of the social rented sector in the context of the welfare state}

The constant tension between government intervention and market influences becomes apparent when we study the development of the social rented sector in the Netherlands. Immediately after World War II the Netherlands had to deal with a serious housing shortages, in common with most Western European countries. The situation 
soon deteriorated, because of the rapid growth in the number of households and low production levels in residential construction in the early post-war period. The shortages that became apparent soon after 1945 made an exceptionally high level of government intervention in homebuilding programs broadly acceptable. Policymakers were faced with escalating costs, ranging from the cost of living to construction costs and interest rates. Thus, substantial object subsidies were needed to contend with the massive housing shortage. A high level of government intervention was called for; this was entirely fitting in a period when the welfare state was gaining ground. In comparison with the rest of Europe, housing production in the Netherlands rose after the 1960s to an unprecedented level. This rapid rate of construction was necessary; during this period, the number of households in the Netherlands increased much more rapidly than in the rest of Europe. The decline in the birth rate came to the Netherlands very late; there was also a postponed, but nevertheless intense decline in average household size. In contrast with the period before 1940, the need to build cheaply and quickly led to an emphasis on the social rented sector. These driving forces helped the sector to expand. The sector's share grew from $12 \%$ in 1945 to $41 \%$ in 1975 and to no less than $44 \%$ of the total stock by the early 1990s. No other Western European country attained such a high share. The eventual turning point in Dutch housing policy was reached in 1989. The remainder of the new policy is strongly geared to the promotion of the market (Heerma, 1989). The Memorandum on Housing for the 1990s [Nota Volkshuisvesting in de jaren negentig] puts particular emphasis on deregulation, decentralization, and self-sufficiency. This new policy line includes the decentralization of authority. The transfer of responsibilities and risks from the State to the local authorities and provinces and the independence of housing associations and (organizations of) housing consumers are featured. For the housing associations, this shift meant that the existing regulations operating in advance were replaced by retrospective accountability (Heerma, 1989). Financial freedom was also markedly increased in addition to freedom in terms of policy. The government decided to phase out the object subsidies for new construction as rapidly as possible. Rents in the period 1990-1994 were raised annually by 5.5\%, a far greater margin than the general level of inflation, and this increase in revenue strengthened the financial position of the associations. The Grossing and Balancing Operation constituted a second important episode marking the move towards financial independence. The State wanted at one and the same time to redeem the long-standing subsidy commitments (15.9 billion euro) and simultaneously call in early the loans that the associations still had outstanding (18,6 billion euro). In this way, the continuous pumping of money round the social housing circuit could be brought to an end. After intensive consultations with the sector, agreement was reached that the Grossing and Balancing Act would take effect in 1995. The advantages for the State were evident: savings were made on the object subsidies, the administrative bureaucracy could be substantially reduced, and the housing budget could be subjected to a stringent cleanout operation. Moreover, the State could take an independent position with respect to the housing association sector in the discussions concerning the annual rent increase. The Act also brought certain advantages for the associations. They traded in supposed savings at one and the same time, became capable through their greater independence of carrying out a more flexible and thus market oriented rental policy, and assumed new responsibilities in the management of their property. The increased rents and the Grossing and Balancing Operation have ensured that the associations have sufficient financial resources at their disposal to be able to carry out the housing task quite independently. In the Netherlands this is referred to by the term revolving fund. .

The government considers the social rented sector in its entirety as a revolving fund that should be capable of functioning without government subsidies. The idea of a revolving fund implies that current and future reserves generated in the social rented sector are put to use within that sector; in this manner, the housing associations 
subsidize themselves. The revolving fund applies both to the sector as a whole and to the individual associations. Each of them has to use the yields of their operations in the current stock to pay for (non cost-effective) new instruments in the quality of the stock, new construction, and improvements in liveability. For the sector as a whole, the yields of the prosperous and the poor associations can be balanced. Prosperous associations could, for instance, support their poor relations by lending them the funds they need at below-market interest rates.

When we look at the situation of the social rented sector in the Netherlands around the second half of the last decennium, the following observations could be made (Boelhouwer and Hoekstra, 2009).

- $\quad$ The pressure on the housing market puts associations in a strong position. The rentability of their housing is excellent. A few years ago they worried about empty accommodation, whereas now supply exceeds demand right across the board.

- Towards the end of the nineteen-nineties, national Government stated that new housing production should concentrate on the market sector. As a result, the associations have built very little social rented housing during the period 2002-2007.

- The financial position is robust. More capital has been accrued than the minimum amount needed, creating room for investment. The composition of the housing supply (age, quality), the development of demand on the housing market and the shift in the attitude of national Government all lead towards a substantial investment programme (2007-2011). There are huge differences in the financial positions of the various associations.

- The image of the sector is decidedly poor. Much of the publicity is negative in tone (high salaries, arrogance, fraud, low housing production in the past).

- The European Union asked for attention to be paid to a fair competitive position in relation to commercial landlords and project developers, and to the size of the target group of the social rented sector.

On the basis of these characteristics, one can conclude that the housing associations had become used to not being held accountable for their actions. The organisations had become distanced from their 'natural owners', the tenants and the Government, and they are neither 'disciplined by the market' nor 'disciplined by the Government'. There was no structural incentive for the associations to make socially acceptable investments. It's important to realise that in practice, housing associations were making a lot of socially acceptable investments. The amount of the investments and the direction are however not controlled or steered by government bodies. On the other hand, most associations felt stifled by the State-dictated policy framework and the legislation and regulations. They found themselves trapped in a bureaucratic web and would like more room for enterprise. In order to face up to the problems described above, a deluge of reports and recommendations appeared in the Netherlands in the period 2004-2006. Alongside all these reports and recommendations, the stance adopted by the European Commission was just as significant in terms of the future positioning of the housing associations. Within the context of the European regulations on market efficiency and competition, all forms of State assistance that cannot be termed a service of general interest must in principle be reported to the European Commission. In this respect the European Commission's decision of 13 July 2005 to grant the housing sector a general exemption from the obligation to report State assistance is an important one. This 'exemption from notification' can be given because, according to the European Commission, there is only a very limited risk of causing disruption on the internal European market. This means that associations do not have to report every project they undertake involving State assistance to the European Commission. Another condition specified in the decision is that associations must make an administrative distinction for any activities undertaken that do not benefit the public interest. The 
decision applies to all Member States. One day later, on 14 July 2005, Minister Dekker received a supplementary letter from the European Commission. In this letter, the European Commission indicated that it considers the financing of housing associations in the Netherlands to be a form of existing support. In other words, it is seen as support that was in place prior to 1957 and which is therefore not subject to debate with retrospective effect. All forms of existing support will however be subject to continued scrutiny in respect of developments on the common market. The European Commission can advise Member States of the measures they should take to preserve the qualification 'existing support' for the future.

The European Commission then assessed the support given to the associations in terms of compatibility with the European regulations on the common market. The Commission was of the opinion that the Dutch Government should introduce the following three measures:

- $\quad$ housing associations activities with State assistance should not only be directly linked to the maximum value of houses, but also to socially deprived households;

- $\quad$ any commercial operations undertaken by the housing associations should be subject to market conditions, and profits made from commercial activities must be reinvested in the social house building sector;

- $\quad$ excessive and structural over-capacity of social housing should be prevented by selling these houses, and the over-capacity should be restricted to a small percentage of the total housing supply.

The Brussels rules were formally introduced in the Netherlands in January first of the year 2011. In June 2011, Minster Donner also sent a first draft of a new Housing act to the parliament. This document was based on six years discussion and several letters and policy documents of three former ministers. The housing associations have been given two concrete tasks: the primary allocation of regulated rented housing to targeted income groups and investment in house building and restructuring. The primary allocation to targeted income groups is based on an income of 33.614 euros per year (1 jan. 2011 and indexed every year; approximately 39\% of all Dutch households have an income below this threshold and approximately $76 \%$ of the current allocations is beneath this ceiling). $10 \%$ of the yearly allocations of the housing associations may be directed to households with a higher income (especially meant for households with an urgent request, with specific needs and from restructuring areas). Households in social rented accommodation that receive an increase in their income are not directly obliged to move. New housing should provide a sufficiently attractive alternative for these people, according to the Minister.

Another important proposal is to change the role of the Central Fund into a Housing Authority (for an elaboration of the Central fund see section 3). In the case of a bad functioning housing association, the Authority will get the possibility to give instructions to the management board of the housing association. The financial monitoring and control role of the current Central Fund will not be changed. A new task for the Authority is to control the regulations on state support (the Brussels rules). On the basis of this last aspect, housing associations have to make a division in their book keeping in commercial activities and activities under state control (organising housing for the target group and real estate for the use of societal organisations like schools en community centres). Important is also that housing associations still have the opportunity to be active in commercial activities like building housing for the middle income groups and in developing more expensive rented and owner occupied houses. The only conditions are that there will be no state support involved and that these activities are organised at the same conditions as conducted by commercial firms. The minister of Housing will keep supervision on the integrity, the governance and the performance of the housing associations. Also the position of the internal supervisory board is strengthened. They have to give permission for important decisions like the selling of 
houses and big investment proposals. The board is also responsible for the functioning of the management board of the housing association. When the internal supervisory board is not functioning well, the minister has the opportunity to fire the board.

The draft of the new Housing act is more or less in line with the government agreement "Freedom and responsibility", as it was published by the centrum-right wing government in October 2010. It's remarkable that the reforms and proposed budget cuts are mostly focussed on the (social) rented sector. The home ownership sector is almost not mentioned in the agreement and the huge fiscal subsidies to home owners are not discussed at all (deduction of mortgage interest). In the rented sector, the policy of the yearly rent adjustment by inflation is continued. Most important reason for the government to not introduce a more market oriented rent adjustment system is that such a policy would lead to negative effects on the purchasing power of tenants. Only renters with an income of above 43.000 euros per year will be confronted with a rent increase of $5 \%$ plus inflation (at this moment almost $2 \%$ in the Netherlands). This strong rent increase will, however, only effect about $15 \%$ of the total households in the rented sector. A practical problem is how to check the income level. Tax authorities are the only institution who can check income data. They are already complaining about an overload of commitments. Checking the incomes of 2.4 households in social housing is costly, time consuming and sensitive to fraud. The idea is that this rent increase will be implemented per July 2013.

The coalition agreement has most far reaching consequences for the social rented sector in the Netherlands. First of all tenants in the social rented sector, after a similar policy in Great Britain since 1980 receive a right to buy. This proposal is introduced to stimulate home ownership furthermore and to compensate the landlords for a big property tax which will be introduced in 2014 and has to raise 760 million euros every year (620 million euros for housing associations; 140 million euros for commercial real estate investors). Government wants that landlords will pay part of the costs on housing allowances. The idea to introduce a right to buy is quite new and was not discussed before the election. By now the government is quite hesitating about this firm statement. It is obvious that housing associations in the Netherlands are private organisations which cannot be expropriated without compensation (Boelhouwer, 2007). The coalition government had to resigned in April 2012 and announced new elections for September 2012. To reduce the government deficit to below 3\%, a coalition of government and opposition parties agreed after the fall of the government to cut another 12.4 billion euro on the government budget for the year 2013. The were also some remarkable housing marker reforms introduced. The most remarkable idea is to mitigate the mortgage tax relief for first time buyers. For the rented sector, not many new proposals were presented. The most important change is that renters with in yearly income between 33.000 and 43.000 euros per year will be confronted with a rent increase of $1 \%$ plus inflation. For housing associations, this means that that there will be three different rent increases, depending on the income of the household.

\section{Financing in the social rented sector}

Until the beginning of the 1980s, the financing needs of the Dutch housing associations were covered via loans granted by the State. These loans exerted a direct pressure on the national budget. In the 1980s, the government came into serious financial problems, saw the national debt rising rapidly, and so decided in 1984 to abolish the provision of loans to associations and also the counter-guarantees provided by the State for loans borrowed on the capital market. In 1983, the Social House-building Guarantee Fund (WSW) [Waarborgfonds Sociale Woningbouw] (WSW) was set up as a private law institute to enable the financing needs of associations to be covered. At first, only guarantees for housing improvement were concerned. Five years later, it also became possible to obtain guarantees 
for the financing of the construction of new dwellings. The WSW endeavours to provide the participating associations with access to the capital market at the lowest costs. Since that time, the WSW has granted guarantees to moneylenders for loans for new construction, housing improvement, the acquisition of dwellings and nursing and retirement homes. The WSW is not, however, the only institute that makes guarantees available. Local authorities also grant guarantees for housing associations' loans, albeit on a limited scale.

If housing associations borrow with loan guarantees provided by the WSW, there is a triple guarantee. The primary security is formed by the financial resilience of the association itself and of the entire sector through the participation of the Central Fund (see below). The secondary security consists of the capital assets of the WSW, which are created by a single capital contribution from the State and the fees the associations pay to obtain guarantees. The tertiary security is formed by the ultimate responsibility of the State and the local authorities that share this task equally (Van der Schaar, 1991, p.404). The attractive interest rates on loans secured by the WSW demonstrate the great confidence that lenders have in the fund. Their confidence is largely due to the ultimate security provided by the State (Priemus, 1995).

A housing association wishing to use the facilities of the WSW must first register with the fund. Before the WSW approves an application, it tests the creditworthiness of the applicant. Before 2007, the evaluation of the financial position of an association is based on its assets. Since 2007 however, the yearly cash flow of the housing association must be positive. This means that even associations with a high solvency (but were the money is mainly bounded in the stones) could have problems in attracting loans.

The WSW has been awarded two ratings. The world's leading rating agencies, Standard \& Poor and Moody's Investors Service, have awarded WSW with their highest possible ratings of AAA and Aaa, respectively (WSW, 2011).

At the end of 2010, most of the social landlords were registered with the WSW. The total secured capital of the WSW had risen by the end of 2010 to around 85,3 billion euro. For the near future, the Dutch housing associations expect to invest a total of around 40,4 billion euro between 2011 and 2016, most of which will be funded externally (WSW, 2011).

WSW has also an important monitoring function and is keeping in sight all developments that effects social housing. Therefore WSW:

- $\quad$ assesses its participants' financial positions as well as their overall quality;

- devotes attention to its participants' cash flows

- $\quad$ analyses the market on an on-going basis;

- $\quad$ requires participating housing associations to provide information twice a year and asks for both actual and forecast figures;

- $\quad$ advises participants on the range of products available in the market;

- $\quad$ is actively involved in developing new financial products for the sector (WSW, 2011).

In addition to the WSW, the Netherlands has a second important institute: the Central Housing Fund [Centraal Fonds voor de Volkshuisvesting] (CFV). This fund is responsible for two important tasks: financial supervision (since 1998), and financial reconstruction (since 1988). Associations in a poor financial position can appeal to the CFV for assistance. According to the draft Housing act, the Central fund will be transformed into a new Housing Authority. 
The CFV is a mutual fund established by and for the associations. Its purpose is to support financially weak associations and, where necessary, help them restructure their operations. To this end, each association contributes annually to the fund. The size of the contribution required from an association is calculated on the basis of its financial situation and, since 2001, whether it has given financial assistance to another association that does not have enough capital to finance some specific projects. An association that fails to qualify for (further) participation or guarantees from the WSW can appeal to the CFV for help. The CFV will provide an interest-free loan to an impoverished association on condition that it becomes self-supporting within three years. Sometimes, this condition requires the restructuring of an association. In many cases, its management is taken over by a member of the CFV. In principle, the CFV contributes half the cost of such an operation. The other half is usually borne by the local authority that is also ultimately responsible for housing. The conditions imposed by the CFV for support closely reflect those operated by the WSW in assessing an association's creditworthiness (Gruis, 1997, p.18). Since its existence, financial support amounting to over 500 million euro has been granted to eighteen housing associations.

In addition to its financial reconstruction task, since 1998 the CFV has also undertaken a supervisory task that features early-warning monitoring. Through the fund's timely signalling of an association's financial weakness to the national government, it can intervene as a formal supervisor. As a result, as far as possible any financial problem affecting an association can be avoided. In this context, the CFV has been given a number of specific new tasks. In the first place comes the signalling task related to the assessment of the likelihood of future cases needing financial reconstruction. For this purpose, the CFV compiles reports on the financial position of individual associations. These reports are based on the associations' annual reports and supplementary information they may provide. Furthermore, the CFV advises the State over the financial aspects of new admissions, mergers, and any changes in the statutes. The CFV also reports each year on the financial situation of all the housing associations taken as a whole. It was announced that the financial position of the sector in the 2010 financial year could be considered to be healthy. The solvency position of only four housing associations is in jeopardise; the value of their assets is too low for their investment plans. The operation costs are another point of attendance for the CFV. These have been far above inflation in the last few years, and differ between $5 \%$ and $10 \%$. On the basis of these figures one could wonder if the housing associations do operate efficiently. After a lot of criticism from the CFV and the central government, the operation costs went finally down to 'only' 3\% in 2009 (much less than the years before, but still more than the inflation rate of $1,2 \%$ ). Also the umbrella organisation AEDES is aware of this problem. They ordered that the operation costs of the housing associations should go down with $20 \%$ in the years to come. The yearly report from the CFV also stated that the housing associations were quite successful in combating the economic crisis and were able to invest on an anti-cyclical basis. The years 2008 and 2009 were in many ways excellent years: the production of owner occupied and rented accommodation, renewal activities, and the spending on liveability all boomed. The year 2010 can be seen as turning point. After 2010, mainly because of less income and taxing by the government, the activities of the housing associations will probably go down substantially (Central Fund, 2011, p.7.)

\section{The future of the social rented sector}

Encapsulated in the above description is a warning that, over the next few years, the Dutch social rented sector must reconsider its position. This follows from the changes in the arrangements of the Dutch welfare state and the subsequent shifts in the redistribution of income, because of the new Brussels rules on competition as well as from the autonomous developments in the housing market. An other important reason is the financial mismanagement of some housing associations in recent years. Several housing associations got them self in huge problems by speculation 
with financial derivatives (interest Swaps). For instance the biggest housing association in The Netherlands (Vestia) lost around 2 billion euros in 2012.

There are several possible scenario's for the future of the Dutch housing associations, which are connected to the future development of the welfare state.

\section{Continuation of the current system}

Maybe the most likely outcome of the debate about the future of the Dutch housing associations is to adjust the current system on the new Brussels rules and to avoid any further disasters. This direction fits perfectly well with the consolidation of the modern corporatistic welfare state and is also in line with the recent proposals to modify the housing act, which were introduced by the Minister of housing and approved by the Dutch parliament in July 2012. To solve the current governance problems and to avoid future financial disasters, governance by central government will be tightened a little bit and treasury rules will be more restrictive in general and more specific for the use of financial derivates (more or less the same way as municipalities are threated). Secondly, the tasks of the housing associations will be divided in a for profit and a not for profit part. There could be an administrative division in the housing association between activities for the target group (household income below 33.600 euros) and for the non-target group. For this last group there will be no state aid like WSW support or cheap land provided by municipalities. This separation of activities will create a level playing field with the commercial sector. Also the internal governance of the housing associations could improved and professionalized further more.

\section{Opting out}

An another opposite policy direction is that the government will retreat completely, and that housing associations will be non-profit organisations without any government support. This is an extension of the gross and balancing operation from the nineties. It also means that the government support to the WSW will be ended and that housing associations like in Germany will be treated like commercial landlords. The revolving fund will ensure that housing associations will still be able to house low income and other deprived groups. For many housing associations, this will be a bright future. No more squeezed government regulations and freedom to act. Also the recently introduced taxes for housing associations could be ended. Two years ago a housing association tried to leave the non-profit system. This was however opposed in court. Against this background, it's highly doubtful if central government will support such an opting out movement. This will only be negotiable if housing associations will hand in a huge part of their financial reserves to the central government. Furthermore, the government is by constitution still responsible for also housing vulnerable groups in society. It will be very difficult to fulfil this task if there are no possibilities left to steer the housing associations.

\section{Functional organisational split}

In the Split-function variant, a division is created between the actual activities of the housing association and its capital (see also Boelhouwer and Priemus, forthcoming). Some scholars (Conijn, 2011) are arguing that social landlords are far from efficient and should work more cost effective and should be more influenced by market forces. Most of the housing associations currently have the legal form of a foundation. In order to create a legally valid division between capital and management activities, the foundation will have to set up a new company to which all real activities of the housing association (ownership of the property, management and development) are transferred. The foundation then only holds the shares in this company. The new company acts as a regular commercial asset management company and strives to achieve good profits on the exploitation and development 
of the rental property. The profits are either distributed as dividend to the shareholder (= the foundation) or invested with the aim of increasing the profits in the future - which will once again go to the shareholder. The original housing association (= the foundation) is thus converted into an investment fund and asset management firm; the only link between it and the company is that it holds the shares in the latter. A possibility is that the fund is still governed by the provisions of the Besluit beheer sociale huursector (Social Rental Sector Management Order; Dutch abbreviation: BBSH). In accordance with the terms of this Order, surpluses are to be used in the interests of social housing in conformity with guidelines drawn up by Parliament. The obligation to use the housing association's capital in the interests of social housing is thus also preserved in this variant.

\section{From real estate manager to capital manger: the opting in of private capital}

An extension of the organisational split is to fully integrate private investment capital in the housing associations sector. This variant is in line with the development from a modern corporatist welfare state to a more liberal orientated welfare state and will result in a firm paradigm shift. Such a shift seems not very likely against the history of the Dutch welfare state. In this variant, there will be a new business firm who owns more than half of the shares in the company. These shares will be bought by private investors like pension funds and insurance companies. The new shareholders will receive their share of the company's dividends. Of course the housing associations will be compensated for the transfer of shares and will be transformed in a trust who can invest in all kind of societal demands which are not served by the market (for instance lower the rents for low income groups or invest in liveability measures). The shares of the new business firm are in principle freely tradable and more private capital is welcome to invest in the firm. The funds (foundations) will sell part (preferably the greater part) of their shares to the new firm and invest the yield in other equities. This thus creates an economic as well as a legal separation between activities and capital. Like in the functional organisational split, the economic separation has the advantage that an external shareholder can exert more effective pressure on the management to operate efficiently. Pension funds are typically likely to be interested in acquiring the shares, as long as the relationship between yield and risk is favourable. Since there are benefits of scale in asset management, it is conceivable that the funds (foundations) might be interested in making use of one or more common asset management companies. In 2012, such a proposal was launched by group of housing experts, former politicians and investors (Forum for Housing and Living, 2012). However, Boelhouwer and Priemus (forthcoming) point out some negative consequences of this choice. The more liquid nature of the capital will increase the temptation to squander the assets. Another potential problem is that the politicians will have to relinquish their discretionary control of rental policy in order to attract new potential shareholders.

As mentioned before, the continuation of the current situation with a stronger role of the government in their role as external supervisor fits best to the current modern corporatistic welfare state in the Netherlands. We can only interpret the functional organisational split function and the opting in and out variants as a prelude to the complete transformation of the housing association as a non-profit organisation with a hybrid character, where the orientation towards a target group and the obligation to devote its capital to a specific (social) purpose in conformity with the Housing Act remain essential components, to a fully fledged commercial market player where the interests of the shareholders will in the long run prevail over the dedication to a particular target group and the obligation to use the funds for a particular purpose. In our opinion, this comes down to throwing the baby away with the bathwater. Housing associations have in the past made an essential contribution to maintaining social housing in the Netherlands at a proper level. They can continue to play this role if certain conditions are 
met. We are therefore convinced that the adapted current system is to be preferred over the split-function and opting in variants.

\section{Conclusions}

The central question posed at the outset of this paper is how to explain the position of the Dutch social rented sector in the country's housing system. It has been established that the position of the social rented sector is strongly influenced by developments in society at large. In particular, its specific position may be explained with reference to the emergence and transformation of the Dutch welfare state. For example, until the 1950s, the social rented sector in the Netherlands was quite modest (12 per cent of the dwelling stock), even compared to other European countries. After the Second World War, the welfare state - a phenomenon that was at first only weakly developed in the Netherlands - grew to maturity at an extremely rapid pace. In fact, the Dutch 'lag' behind other countries in Western Europe turned into a comfortable 'lead' in a few decades. Moreover, the welfare state remained in full glory much longer in the Netherlands. The turning point did not come until the mid-1990s. In most other West European countries, government influence on processes in civil society had already been radically reduced in favour of market forces during the 1970s. In the Netherlands, the development of the social rented sector thus coincided with the vigorous build-up of the welfare state. That sector continued to grow in the Netherlands for a longer period than in most other West European countries. Ultimately, the share of the Dutch social rented sector reached its highest point -41 per cent of the stock - at the beginning of the 1990s.

Against this development perspective, this contribution has shown the uniqueness of the maturation of the Netherlands social rented sector in an international perspective. Not only does the Netherlands have, with $33 \%$ of the total housing stock, far and away the largest social rented sector in Europe, but also independence and substantial accumulated capital in the existing stock. Thanks to the opportunities of rent pooling, the input of the accumulated capital, and the freedom to dispose of real estate so that capital invested in bricks and mortar can be put towards other objectives, the housing associations are able to rent out newly constructed social rented dwellings at well below cost price. The usual unprofitable top of 70,000 euro for the construction of a social rented dwelling is currently substantially higher than the object subsidies that the State government granted at the beginning of the 1990s. Financing needs can also be met entirely via the WSW so that, in addition to being able to obtain sufficient capital, borrowing on the international capital market is against keen tariffs. This unique situation has been brought about through mutual cooperation and solidarity, and not least through the safety net function of the State. Impoverished associations are also restructured via the CVF through the sector itself. For the future, however, the strong financial position of the associations may also constitute a danger. Now that the national government is being threatened by financial heavy going because of the economic crisis, politicians in particular are looking covetously at the associations' accumulated capital. A first attack on their financial position is the 620 million euros the housing associations have to pay from 2014 onwards on the basis of a new property tax for landlords. Also municipalities are in financial bad weather, and are trying more and more to transfer costly activities to the housing associations.

\section{Literature}

Boelhouwer, P.J., 2007, The Future of Dutch housing associations. Journal of Housing and the Built Environment 22, nr.4, pp.383-391. 
Boelhouwer P.J. and H.M.H. van der Heijden, 1992, Housing Systems in Europe: Part I, A comparative study of housing policy. Housing and Urban Policy Studies 1, Delft: Delft University Press.

Boelhouwer, P.J. and J. Hoekstra, 2009, Towards a better balance on the Dutch housing market? Analysis and policy proposition, European Journal of Housing Policy 9, nr.4, pp.457-475.

Boelhouwer, P. and J. Hoekstra, 2012, Housing and the state in Western Europe. In: S.J. Smith, M. Elsinga, L. Fox O'Mahony, O. Seow Eng, S. Watcher, C. Hamnett, editors. International Encyclopedia of Housing and Home, Vol 3. Oxford: Elsevier; 2012, pp.363-373.

Boelhouwer, P. and H. Priemus, forthcoming, Housing system reform: the opinion of advisory board versus political reality in the Netherlands. Journal of Housing and the Built Environment.

Centraal Fonds Volkshuisvesting [Central Housing Fund], 2011, Jaarverslag 2010[Annual Report 2010]. Huizen $(\mathrm{CFV})$.

Conijn, 2011, Woningcorporaties op een kruispunt. Amsterdam, Amsterdam School of Real Estate.

Danermark, B. and I. Elander, 1992, Social rented housing in Europe: policy, tenure and design. Housing and Urban Policy Studies 9, Delft: Delft University Press.

Esping-Andersen, G., 1990, The Three Worlds of Welfare Capitalism, Cambridge: Polity Press.

Forum for Housing and Living, 2012, Woningcorporaties op eigen benen: verdienen om te kunnen dienen. Naarden.

Gruis, V., 1997, The Netherlands. In: P.J. Boelhouwer, Financing the social rented sector in Western Europe. Pp.7-20. Delft (Delft University Press).

Harloe, M., 1995, The People's Home? Social Rented Housing in Europe and America, Oxford UK and Cambridge USA: Blackwell.

Heerma, E., 1989, Nota volkshuisvesting in de jaren negentig [Memorandum on Housing in the 1990s], The Hague (ministerie VROM).

Kemeny, J., 1995, From Public Housing to the Social Market: rental policy strategies in comparative perspective. London: Routledge.

Kemeny, J., 2006, Corporatism and housing regimes, Housing, Theory and Society 23, no.1. pp. 1-18. 
Priemus, H., 1995, How to abolish social housing? The Dutch case, International Journal of Urban and regional Research 19, nr.1.

Schaar, J. van der, 1991, Volkshuisvesting een zaak van beleid. [Social housing: a matter of policy]. Utrecht (The Spectrum).

Torgersen, U., 1987, Housing: the wobbly pillar under the welfare state. In: B. Turner, J. Kemeny and L. Ludqvist, Between state and market: Housing in the post-industrial era, pp. 116-127 (Almqvist \& Wiksell International).

Waarborgfonds Sociale Woningbouw [Social House-building Guarantee Fund] (WSW)., 2011, Jaarverslag 2010. Huizen (WSW). 




\section{OTB - Research for the Built Environment}

Delft University of Technology

Jaffalaan 9, 2628 BX Delft, The Netherlands

Postbus 5030, 2600 GA Delft, The Netherlands

Phone $+31(0) 152783005$

Fax +31 (0)15 2784422

E-mail mailbox@otb.tudelft.nl

www.otb.tudelft.nl 